\title{
Energetic values of animal by-products for broiler chickens of different ages
}

\author{
Valores energéticos de subprodutos de origem animal em frangos de corte de diferentes idades \\ Valores energéticos de subproductos animales en pollos de engorde de diferentes edades
}

Received: 04/30/2021 | Reviewed: 05/09/2021 | Accept: 05/16/2021 | Published: 06/03/2021

José Luiz Schneiders

ORCID: https://orcid.org/0000-0001-8703-8279

Universidade Estadual do Oeste do Paraná, Brazil

E-mail: ze.luiz@zootecnista.com.br

André Sanches de Avila

ORCID: https://orcid.org/0000-0002-8351-8547

Universidade Estadual do Oeste do Paraná, Brazil

E-mail: sanches989@hotmail.com

Jomara Broch

ORCID: https://orcid.org/0000-0002-0799-9473

Universidade Estadual do Oeste do Paraná, Brazil

E-mail: brochjomara@yahoo.com.br

Rafael Frank

ORCID: https://orcid.org/0000-0003-0745-4737

Universidade Estadual do Oeste do Paraná, Brazil

E-mail: rafaelfrankrafael@hotmail.com

Rodrigo André Schöne

ORCID: https://orcid.org/0000-0001-5235-2997

Universidade Estadual do Oeste do Paraná, Brazil

E-mail: rodrigoschone87@gmail.com

Tiago Rafael Hofferber

ORCID: https://orcid.org/0000-0003-3815-0189

Universidade Estadual do Oeste do Paraná, Brazil E-mail: tiago_hofferber@hotmail.com

Guilherme Luis Silva Tesser

ORCID: https://orcid.org/0000-0003-0187-0027

Universidade Estadual do Oeste do Paraná, Brazil

E-mail: guilherme_tesser@hotmail.com

Edinan Hagdon Cirilo

ORCID: https://orcid.org/0000-0001-7628-2870

Universidade Estadual do Oeste do Paraná, Brazil

E-mail: edinancirilo@hotmail.com

Nilton Rohloff Junior

ORCID: https://orcid.org/0000-0002-7146-7295

Universidade Estadual do Oeste do Paraná, Brazil E-mail: nilton_rohloff_8@hotmail.com

Cleison de Souza

ORCID: https://orcid.org/0000-0001-5379-2759

Universidade Estadual do Oeste do Paraná, Brazil

E-mail: cleisondsz@hotmail.com

Ricardo Vianna Nunes

ORCID: https://orcid.org/0000-0002-9376-2826

Universidade Estadual do Oeste do Paraná, Brazil

E-mail: nunesrv@hotmail.com

\begin{abstract}
The objective of this study was to determine the chemical composition and apparent metabolizable energy (AME), AME corrected for nitrogen balance (AMEn) and its respective metabolizable coefficients of animal byproducts for broiler chickens with different ages. Meat and bone meal, poultry by-product meal, tilapia processing residue and poultry fat were evaluated. A total of 760 male broiler chickens were used and evaluated and the phases: pre-starter (1 to $8 \mathrm{~d}$ of age); starter (11 to $18 \mathrm{~d}$ ); grower 1 (21 to $28 \mathrm{~d}$ ); grower 2 (31 to $38 \mathrm{~d}$ ), and finisher (41 to $48 \mathrm{~d}$ ). Total excreta collection method was performed in five metabolism assays. The experimental design was completely randomized, and data were submitted to analysis of variance, posteriorly, the four feeds were compared by Tukey test and a regression analysis was performed with broiler chickens age. The significance was considered at 5\% probability. The values of AME and AMEn were higher in older birds for all ingredients. The lesser CAME and CAMEn were obtained for meat and bone meal, for the regression analysis poultry by-product meal, tilapia processing residue and poultry fat had an increased linear effect with birds age and there was no adjust for meat and bone meal for regression analysis.
\end{abstract}


Keywords: Alternative feeds; Metabolism assay; Metabolizable energy.

\begin{abstract}
Resumo
O objetivo deste estudo foi determinar a composição química e energia metabolizável aparente (EMA), EMA corrigida para o balanço de nitrogênio (EMAn) e respectivos coeficientes de energia metabolizável de subprodutos de origem animal em frangos de corte de diferentes idades. Os quatro alimentos avaliados foram: farinha de carne e ossos, farinha de vísceras, farinha do resíduo do processamento da tilápia e gordura de aves. Um total de 760 frangos de corte machos foram utilizados e avaliados nas fases: pré-inicial ( 1 a 8 dias de idade), crescimento 1 ( 21 a 28 dias); crescimento 2 (31 a 38 dias) e terminação ( 41 a 48 dias). Foi realizado o método de coleta total em cinco ensaios de metabolismo. O delineamento experimental foi inteiramente casualizado e os dados foram submetidos à análise de variância e as médias dos quatro alimentos foram comparados pelo teste de Tukey, também foi realizada análise de regressão para a idade das aves, a significância foi considerada a 5\% de probabilidade. Os valores de EMA e EMAn foram maiores nas aves com idades mais avançadas para todos os ingredientes e os menores coeficientes de metabolizabilidade ocorreram na farinha de carne e ossos. Na análise de regressão os valores energéticos da farinha de vísceras, farinha do resíduo do processamento de tilápia, e gordura de aves apresentaram um aumento linear com a idade das aves e não ocorreu ajuste para a farinha de carne e ossos.
\end{abstract}

Palavras-chave: Alimentos alternativos; Energia metabolizável; Ensaio de metabolismo.

\title{
Resumen
}

El objetivo de este estudio fue determinar la composición química y energía metabolizable aparente (EMA), EMA corregido para el balance de nitrógeno (EMAn) y sus coeficientes de energía metabolizable de subproductos de origen animal en pollos de engorde de diferentes edades. Los cuatro alimentos evaluados fueron harina de carne y huesos, harina de vísceras, harina del residuo del procesamiento de tilapia y grasa de ave. Se utilizaron y evaluaron un total de 760 pollos de engorde machos en las fases: preinicial ( 1 a 8 días de edad), crecimiento 1 ( 21 a 28 días); crecimiento 2 (31 a 38 días) y terminación (41 a 48 días). El método de recolección total de heces se llevó a cabo en cinco ensayos de metabolismo. El diseño experimental fue completamente aleatório, los datos fueron sometidos a análisis de varianza y los cuatro alimentos se compararon mediante la prueba de Tukey, también se realizó un análisis de regresión para la edad de las aves, la significancia se consideró al 5\% de probabilidad. Los valores de EMA y EMAn fueron mayores en aves con edades más avanzadas para todos los ingredientes y los coeficientes de metabolizabilidad más bajos ocurrieron en la harina de carne y huesos. En el análisis de regresión, los valores energéticos de la harina de vísceras, harina de residuos de procesamiento de tilapia y grasa de ave mostró un aumento lineal con la edad de las aves y no hubo ajuste para la harina de carne y huesos.

Palabras clave: Alimentos alternativos; Energía metabolizable; Ensayo de metabolismo.

\section{Introduction}

The dependence of the poultry sector on corn and soybean meal generates demand for alternative products, as lowcost feed sources (Dalólio et al., 2019), in this context, the use of by-products from animal origin is an important strategy to reduce production costs, besides, it can provide an appropriate destination for the waste generated by the industries and slaughterhouses (Eyng et al., 2011).

The use of by-products in poultry diets makes necessary precise knowledge of its chemical composition and metabolizable energy, providing a formulation with lower cost and efficient use of energy by birds (Mariano et al., 2012; Vieira et al., 2015). Protein by-products of animal origin are important sources of energy, amino acids, calcium and phosphorus, however, the lack of standardization in the production process leads to variations in the levels of nutrients and energy (Troni et al., 2016). These variations in the nutrient profile occur due to the addition of bones, blood, heads, lean tissues, viscera, hooves, hide, feathers, and fat besides the differences in processing methods and conditions (Adeola et al., 2018).

Broiler chickens need a high-energy diet to support its rapid growth and metabolism (Cao \& Adeola, 2016), so fat sources are also important ingredients to increase dietary energy levels and are becoming an essential component in the formulation of high energy broiler diets. Besides other benefits of adding fats include improved feed texture, reduced dustiness, and increased palatability (Tancharoenrat et al., 2013; Rodriguez-Sanchez et al., 2019).

The ability of animals to extract nutrients from feeds most likely increases with age with the most drastic changes in 
the first few weeks of life, and such age-related increases could be substrate-associated and therefore dependent on feed ingredient (Adeola et al., 2018). It demonstrates the importance of determining the metabolizable energy of feeds at different broiler chickens ages (Schneiders et al., 2017).

The objective of this study was to determine the values of apparent metabolizable energy and apparent metabolizable energy corrected for the nitrogen balance and its respective coefficients of metabolizability for different by-products of animal origin, with broiler chickens at different ages.

\section{Methodology}

The experiment was carried out at the Poultry Research Center of Western Paraná State University (Marechal Cândido Rondon, PR, Brazil) and the experimental procedures were approved by the Animal Ethics Committee of the University under number 026/09.

A total of 760 male, one-day-old (Cobb 500) broiler chickens were obtained from a commercial hatchery and raised on a concrete floor covered with pine wood shavings, receiving a diet based on corn and soybean meal, and water ad libitum. When the broiler chickens reached to the respective ages, they were transferred to the metabolic cages, which were equipped with trough type feeders and drinkers. The room temperature was kept within the ideal thermal comfort zone indicated for each phase, according to the strain recommendations (Cobb-Vantress, 2008).

Broiler chickens were distributed in a completely randomized design with four treatments (feeds) and five replications (the cages were considered the experimental units - EU). Each assay lasted eight days consisting in three days for adaptation and five for collections, which were performed according to Sibbald \& Slinger (1963), in intervals of 12 hours to avoid possible fermentations (Rodrigues et al., 2005).

The phases evaluated were pre-starter (1-8 d) with 300 birds; starter (11-18 d) 200 birds; grower 1 (21-28 d) 100 birds; grower 2 (31-38 d) 80 birds, and finisher (41-48 d) 80 birds. The four ingredients evaluated were: meat and bone meal (MBM), poultry by-product meal (PBM), tilapia processing residue (TPR) and poultry fat (PF). Five reference rations (RR) based on corn and soybean meal (Table 1) were formulated to meet the recommendations proposed by Rostagno et al. (2011). The MBM, PBM and TPR replaced the RR at $200 \mathrm{~g} \mathrm{~kg}^{-1}$ and PF replaced the RR at $100 \mathrm{~g} \mathrm{~kg}^{-1}$. 
Table 1. Chemical composition of feeds $\left(\mathrm{g} \mathrm{kg}^{-1}\right.$ as fed) and reference rations for broiler chickens at different ages.

\begin{tabular}{|c|c|c|c|c|c|}
\hline \multirow{2}{*}{ Item $\left(\mathrm{g} \mathrm{kg}^{-1}\right)$} & \multicolumn{5}{|c|}{ Age (days) } \\
\hline & $1-8$ & $11-18$ & $21-28$ & $31-38$ & $41-48$ \\
\hline Ground corn & 530.4 & 565.2 & 591.2 & 621.6 & 656.0 \\
\hline Soybean meal & 398.4 & 359.7 & 326.3 & 296.2 & 269.0 \\
\hline Soybean oil & 26.8 & 34.8 & 45.0 & 46.6 & 40.2 \\
\hline Dicalcium phosphate & 19.3 & 18.3 & 16.9 & 15.3 & 14.4 \\
\hline Limestone & 9.30 & 9.00 & 8.50 & 8.10 & 7.90 \\
\hline Sodium chloride & 5.20 & 5.00 & 4.80 & 4.50 & 4.40 \\
\hline DL-met & 3.60 & 2.60 & 2.40 & 2.30 & 2.20 \\
\hline L-lys & 3.00 & 2.00 & 1.80 & 2.10 & 2.50 \\
\hline L-thr & 1.20 & 0.60 & 0.40 & 0.50 & 0.60 \\
\hline Vitamin premix $^{1}$ & 1.00 & 1.00 & 1.00 & 1.00 & 1.00 \\
\hline Mineral premix ${ }^{2}$ & 0.50 & 0.50 & 0.40 & 0.50 & 0.50 \\
\hline Choline chloride (60\%) & 0.60 & 0.60 & 0.60 & 0.60 & 0.60 \\
\hline Anticoccidian $^{3}$ & 0.50 & 0.50 & 0.50 & 0.50 & 0.50 \\
\hline Growth promoter ${ }^{4}$ & 0.10 & 0.10 & 0.10 & 0.10 & 0.10 \\
\hline Antioxidant $^{5}$ & 0.10 & 0.10 & 0.10 & 0.10 & 0.10 \\
\hline \multicolumn{6}{|c|}{ Calculated Composition $\left(\mathrm{g} \mathrm{kg}^{-1}\right)$} \\
\hline Met. energy $\left(\mathrm{kcal} \mathrm{kg}^{-1}\right)$ & 2,960 & 3,050 & 3,150 & 3,200 & 3,200 \\
\hline Crude protein & 230 & 213.4 & 200 & 189.1 & 180 \\
\hline Calcium & 9.42 & 8.99 & 8.37 & 7.75 & 7.40 \\
\hline Available phosphorus & 4.71 & 4.49 & 4.18 & 3.86 & 3.68 \\
\hline Sodium & 2.24 & 2.18 & 2.08 & 1.98 & 1.92 \\
\hline Potassium & 8.78 & 8.17 & 7.63 & 7.16 & 6.76 \\
\hline Dig. met & 6.67 & 5.57 & 5.18 & 4.92 & 4.77 \\
\hline Dig. met + cys & 9.68 & 8.44 & 7.91 & 7.55 & 7.31 \\
\hline Dig. Lys & 13.63 & 11.89 & 10.99 & 10.48 & 10.15 \\
\hline Dig. Ile & 9.03 & 8.38 & 7.80 & 7.30 & 6.87 \\
\hline Dig. Leu & 17.97 & 17.06 & 16.24 & 15.57 & 15.03 \\
\hline Dig. val & 9.55 & 8.92 & 8.37 & 7.89 & 7.49 \\
\hline Dig. Thr & 8.86 & 7.73 & 7.14 & 6.81 & 6.60 \\
\hline Dig. Trp & 2.55 & 2.35 & 2.18 & 2.03 & 1.90 \\
\hline Dig. arg & 14.66 & 13.54 & 12.57 & 11.72 & 10.97 \\
\hline
\end{tabular}

${ }^{1}$ Vitamin premix - guarantee levels per kg of product: Vit. A: 9000 IU; Vit. D3: 2500 IU; Vit. E: 20 IU; Vit. K3: 2500 mg; Vit. B1: 1500 mg; Vit. B2: $6000 \mathrm{mg}$; Vit. B6: $3000 \mathrm{mg}$; Vit. B12: $12000 \mathrm{mcg}$; Biotin: $60 \mathrm{mg}$; Folic acid: $800 \mathrm{mg}$; Nicotinic acid: $25000 \mathrm{mg}$; Pantothenic acid: $12000 \mathrm{mg}$; Se: $250 \mathrm{mg}$; ${ }^{2}$ Mineral premix: Mn: $160 \mathrm{mg}$; Fe: $100 \mathrm{mg}$; Zn: $100 \mathrm{mg}$; Cu: $20 \mathrm{mg}$; Co: $2 \mathrm{mg}$; I: $2 \mathrm{mg}$; ${ }^{3} \mathrm{Coxistac}: \mathrm{salinomicin}$; ${ }^{4}$ Surmax: avilamycin; ${ }^{5}$ B.H.T. Source: Authors.

At the end of each assay, feed intake and the total amount of excreta were measured and the excreta samples were defrosted, homogenized and aliquots were taken for each EU, which was weighed and dried in a forced-air oven at $55{ }^{\circ} \mathrm{C}$ for 72 hours (Silva \& Queiroz, 2002) and subsequently ground in a Willey type mill and stored to perform posterior analyzes. 
For determining the feeds chemical composition, analyzes of dry matter (DM), crude protein (CP), ether extract (EE), ash and the minerals: calcium $(\mathrm{Ca})$, phosphorus $(\mathrm{P})$, magnesium $(\mathrm{Mg})$, sodium $(\mathrm{Na})$ and potassium $(\mathrm{K})$, were performed according to the methodologies described by Silva and Queiroz (2002). Gross energy (GE) analysis was performed with an oxygen calorimetric bomb (IKA C200), and AME was corrected to zero $\mathrm{N}$ retention (AMEn) using the factor of $8.22 \mathrm{kcal}^{-1}$ (Hill \& Anderson, 1958). Geometric mean diameter (GMD) of the MBM, PBM and TPR were determined according to the methodologies of Zanotto and Bellaver (1996).

Based on the analyzes of the chemical composition of feeds and excreta, the AME and AMEn values were obtained by the equations proposed by Matterson et al., (1965) and posteriorly it was obtained the energy metabolizable coefficient.

Data were submitted to analysis of variance (ANOVA) and regression procedure to verify the effects of different ages on the metabolizable coefficients for each feed. The comparison between feeds within the same period was obtained by Tukey's test at 5\% probability using the software SAS version 9.1. (Statistical Analysis System Institute [SAS Institute], (2011).

\section{Results and Discussion}

Chemical composition of MBM in this study showed variations (Table 2) in relation to the values described in the literature. Adeola et al. (2018) evaluated MBM and obtained Ca and P values of 107.7 and $53.3 \mathrm{~g} \mathrm{~kg}^{-1}$ respectively, values above those obtained in the present study for $\mathrm{Ca}$ and $\mathrm{P}$ (90.8 and $43.5 \mathrm{~g} \mathrm{~kg}^{-1}$ respectively). The values of crude fat were also higher (114.5 $\mathrm{g} \mathrm{kg}^{-1}$ ) when compared to the present study $\left(97.7 \mathrm{~g} \mathrm{~kg}^{-1}\right)$, regarding CP values, the authors found $492.3 \mathrm{~g} \mathrm{~kg}{ }^{-1}$ of CP for MBM close to the obtained in this study (512.5 $\mathrm{g} \mathrm{kg}^{-1}$ ). A variation also was found by Anwar et al. (2016) who evaluated three different MBM samples and obtained CP values of 474; 488 and $536 \mathrm{~g} \mathrm{~kg}^{-1}$ and crude fat values of 88 ; 93 and $114 \mathrm{~g} \mathrm{~kg}^{-1}$.

Table 2. Chemical composition of feeds $\left(\mathrm{g} \mathrm{kg}^{-1}\right.$ as fed).

\begin{tabular}{lcccc}
\hline Item $\left(\mathrm{g} \mathrm{kg}^{-1}\right)$ & Meat and bone meal & Tilapia processing residue & Poultry by-product meal & Poultry fat \\
\hline Dry matter & 929.2 & 943.9 & 929.6 & 999,0 \\
Crude protein & 384.5 & 512.5 & 579.0 & - \\
GE $\left(\mathrm{kcal} \mathrm{kg}^{-1}\right)^{1}$ & 3,143 & 4,250 & 4,587 & 9,440 \\
Ether extract & 97.7 & 146.8 & 117.1 & - \\
Ash & 406.9 & 253.7 & 181.2 & - \\
Calcium & 90.80 & 52.60 & 139.7 & - \\
Phosphorus & 43.5 & 32.75 & 66.60 & - \\
Magnesium & 1.3 & 2.10 & 3.25 & - \\
Sodium & 4.5 & 4.60 & 6.05 & - \\
Potassium & 5.0 & 5.80 & 1.55 & - \\
GMD $(\mu \mathrm{m})^{2}$ & 581 & 748 & 774 & - \\
\hline
\end{tabular}

${ }^{1} \mathrm{GE}\left(\mathrm{Kcal} \mathrm{kg}^{-1}\right)$ : Gross energy; ${ }^{2} \mathrm{GMD}$ : geometric mean diameter. Source: Authors.

Meat and bone meal is among the most common animal by-products used in broiler diets with high protein levels and may partially replace soybean meal, besides being a protein source, it is a significant source of available calcium and phosphorus (Caires et al., 2010) and factors such as the ratio of bones to soft tissue, fat removal technique, temperature and cooking duration may also affect the nutritional value of MBM (Adeola et al., 2018). According to Troni et al. (2016) the main 
factor of variation in MBM composition is the percentage of bones used in the mixture and a greater proportion reduces protein content and crude energy and increase its mineral content, wherein this by-product is classified according to its crude protein content, varying from 380 to $360 \mathrm{~g} \mathrm{~kg}^{-1}$ (Troni et al. 2016; Rostagno et al., 2011).

Soares Neto et al. (2019) evaluated tilapia processing waste meal silage containing head, bones, skin, fins, and viscera and obtained lesser content of $\mathrm{CP}\left(337 \mathrm{~g} \mathrm{~kg}^{-1}\right)$ and ash $\left(215 \mathrm{~g} \mathrm{~kg}^{-1}\right)$, and a greater fat content $\left(374 \mathrm{~g} \mathrm{~kg}^{-1}\right)$ compared to the present study, which had CP, ash and EE contents of 512.5; 253.7 and $146.8 \mathrm{~g} \mathrm{~kg}^{-1}$, respectively. Eyng et al. (2013) used TPR in broiler chicken diets with $452.5 \mathrm{~g} \mathrm{~kg}^{-1}$ of $\mathrm{CP}$, demonstrating the broad variation of CP content of this by-product.

The composition of PBM was similar to the obtained by Troni et al. (2016) for CP and EE contents, the authors obtained average values of 582.4 and $121.5 \mathrm{~g} \mathrm{~kg}^{-1}$ respectively, however, the authors obtained lower values for $\mathrm{Ca}\left(57.4 \mathrm{~g} \mathrm{~kg}^{-1}\right)$ and $\mathrm{P}\left(32.9 \mathrm{~g} \mathrm{~kg}^{-1}\right)$. Silva et al. (2014) obtained values for $\mathrm{CP}$, fat, and $\mathrm{Ca}$ of $569.1 ; 138.4$ and $53.2 \mathrm{~g} \mathrm{~kg}^{-1}$ respectively, and the greater difference occurred in the Ca contents compared to this experiment, which agrees with the revision of Silva et al. (2010) who found the higher variation for PBM in mineral content, Ca and P.

In the particle size evaluation, considering the classification of Zanotto and Bellaver (1996), MBM was classified as fine granulometry (GMD less than $600 \mu \mathrm{m}$ ) while PBM and TPR, as medium granulometry (GMD from 600 to $2000 \mu \mathrm{m}$ ), in this classification, feeds with GMD higher than 2,000 $\mu \mathrm{m}$ are considered coarse. The GMD of MBM $(581 \mu \mathrm{m})$ is greater than the obtained by Adeola et al. (2018) (533 $\mu \mathrm{m}$ ) and lesser by those of Anwar et al. (2016) with four MBM samples (622, 781, 875, and $866 \mu \mathrm{m}$ ). The GMD of PBM is greater than those of Silva et al. (2012), who evaluated three samples with 639, 656 and $723 \mu \mathrm{m}$.

Smaller particle size increases the relative surface area of feed and can expose the nutrients to digestive enzymes (Xu et al., 2015), however, very fine particle size may increase passage rate and reduce feed digestibility. On the other hand, birds demonstrate a certain preference for coarser feed particles, which can stimulate the gizzard development and increase digesta retention time, improving feed digestibility (Amerah et al., 2007; Amerah et al., 2008). However, birds may encounter difficulties when consuming very coarse or fine particle sizes (Amerah et al., 2007).

Regarding the AME values (Table 3) MBM at the grower 2 phase $\left(1,785.6 \mathrm{kcal} \mathrm{kg}^{-1}\right)$ was similar to the described by Rostagno et al. (2011) with 1,786 kcal kg-1 for MBM. Lesser energetic values were obtained by Troni et al. (2016) who evaluated two different sources of MBM and obtained AME values of 1,574 and 1,353 kcal kg-1 and AMEn values of 1,283 and 1,088 in broiler chickens from 20 to 24 days, the authors related this difference to the chemical composition of MBM evaluated. Adeola et al. (2018) evaluated MBM and found increasing energetic values with post-hatching age of boiler chickens, the authors emphasized the importance of age-related differences in energy digestibility, being necessary to consider these changes during diet formulation. 
Table 3. Apparent metabolizable energy (AME) and AME corrected by nitrogen balance (AMEn) (as fed) of animal byproducts for broiler chickens at different ages.

\begin{tabular}{lccccc}
\hline \multirow{2}{*}{ Feed } & \multicolumn{5}{c}{ Age (days) } \\
\cline { 2 - 5 } & $1-8$ & $11-18$ & $21-28$ & $31-38$ & $41-48$ \\
\hline \multirow{5}{*}{ Meat and bone meal } & 1,736 & 1,748 & 1,766 & 1,786 & 1,862 \\
Tilapia processing residue & 2,885 & 2,869 & 2,848 & 3,416 & 3,705 \\
Poultry by-product meal & 2,993 & 2,934 & 3,238 & 3,235 & 3,259 \\
Poultry fat & 8,135 & 8,062 & 8,777 & 8,755 & 9,449 \\
& \multicolumn{5}{c}{ AMEn $\left(\mathrm{kcal} \mathrm{kg}^{-1}\right)$} \\
Meat and bone meal & 1,609 & 1,920 & 1,627 & 1,657 & 1,762 \\
Tilapia processing residue & 2,480 & 2,888 & 2,569 & 3,157 & 3,361 \\
Poultry by-product meal & 2,645 & 3,113 & 2,952 & 3,006 & 2,992 \\
Poultry fat & 8,066 & 8,790 & 8,654 & 8,803 & 9,343 \\
\hline
\end{tabular}

Source: Authors.

For the TPR the AME values from d 41 to $48\left(3,705 \mathrm{~g} \mathrm{~kg}^{-1}\right)$ were similar to those described by Eyng et al. (2013) of $3,733 \mathrm{kcal} \mathrm{kg}^{-1}$, however, in the present study, lesser values were obtained for younger broiler chickens.

The AMEn values of PBM at grower 1, grower 2, and finisher phases are similar to those published by Rostagno et al. (2017) with metabolizable energy values of $3,241 \mathrm{~g} \mathrm{~kg}^{-1}$. Silva et al. (2010) obtained higher AMEn mean values for PBM of $3,448 \mathrm{kcal} \mathrm{kg}^{-1}$, as well in the study of Troni et al. (2016) who evaluated two PBM for broiler chickens from 20 to 24 days, and obtained AME values of 3,705 and 3,565 kcal kg-1 and AMEn values of 3,340 and 3,241 kcal kg-1; the authors found a lesser difference in AMEn values between the two different PBM used, and highlighted that is important to use AMEn values when formulating diets at the expense of crude energy.

There were greater values of AME and AMEn in older birds; this increase in AMEn values with the advancing age of birds is caused by the improvement in the nutrient's utilization. This effect is related to digestive enzyme production and absorptive capacity, where increases with age and such age-related increases could be substrate-associated and, therefore dependent on feed ingredient (Adeola et al., 2018). In the present study, all the feeds showed higher AMEn values after 11 days of age, according to Adeola et al. (2018) studies have shown that ME value of a diet is lowest between day 4 and 7 posthatching in broiler chicks followed by an increase with post-hatching age.

The AME values of PF increased with bird's age, where the values in the starter phase $\left(8,135 \mathrm{kcal} \mathrm{kg}^{-1}\right)$ were greater than those of Tancharoenrat et al. (2013) who evaluated different fat sources and obtained AME values for PF of 4,311; 8,066; 8,379 and $8,159 \mathrm{kcal} \mathrm{kg}^{-1}$ for birds with one, two, three and four weeks of age, respectively, being lowest in the first week of birds' age. The authors indicated that the lower fat digestibility and AME value could be explained by the poor physiological capacity to absorb dietary fats in newly hatched chicks, however, in this study lesser AME occurred in both pre-starter (1-8 d) and starter phase (11-18) when compared to the other phases evaluated. The mean values of AME were higher than AMEn in the phases pre-starter (1-8 d), grower 1 (21-28 d), and finisher (41-48 d) for all the feeds evaluated, indicating a positive nitrogen retention, a common effect in birds in ad libitum intake (Kato et al., 2011). The values of CAME and CAMEn (Table 4) were higher for PF compared to other sources, which was expected, since lipids are widely used in broiler diets to increase the dietary energy density, due to its higher apparent metabolizable energy (AME) content in relation to other feedstuffs and is often used to improve dietary energy density to meet the requirements of fast-growing broiler chickens (Skřivan et al., 2018). 
Table 4. Coefficient of apparent metabolizable energy (CAME) and CAME corrected for nitrogen balance (CAMEn) of animal by-products for broilers at different ages.

\begin{tabular}{lccccccc}
\hline Feed & \multicolumn{7}{c}{ Age (days) } \\
\cline { 2 - 7 } & $1-8$ & $11-18$ & $21-28$ & $31-38$ & $41-48$ & CV $(\%)^{1}$ & Regression \\
\hline \multirow{3}{*}{ Meat and bone meal } & \multicolumn{7}{c}{ CAME (\%) } \\
Tilapia processing residue & $55.2^{\mathrm{c}}$ & $55.8^{\mathrm{c}}$ & $56.2^{\mathrm{c}}$ & $56.8^{\mathrm{d}}$ & $59.4^{\mathrm{d}}$ & 6.093 & NS \\
Poltry offal meal & $67.6^{\mathrm{b}}$ & $67.6^{\mathrm{b}}$ & $67.0^{\mathrm{b}}$ & $80.4^{\mathrm{b}}$ & $87.0^{\mathrm{b}}$ & 16.152 & Lin \\
Poultry fat & $65.2^{\mathrm{b}}$ & $64.0^{\mathrm{b}}$ & $70.6^{\mathrm{b}}$ & $70.4^{\mathrm{c}}$ & $71.0^{\mathrm{c}}$ & 7.650 & Lin \\
& $86.0^{\mathrm{a}}$ & $85.4^{\mathrm{a}}$ & $92.8^{\mathrm{a}}$ & $92.8^{\mathrm{a}}$ & $99.6^{\mathrm{a}}$ & 6.278 & Lin \\
\cline { 2 - 8 } Meat and bone meal & $51.2^{\mathrm{c}}$ & $61.2^{\mathrm{c}}$ & $51.6^{\mathrm{c}}$ & $52.6^{\mathrm{d}}$ & $56.0^{\mathrm{d}}$ & 10.105 & NS \\
Tilapia processing residue & $58.2^{\mathrm{b}}$ & $67.8^{\mathrm{b}}$ & $60.6^{\mathrm{b}}$ & $74.2^{\mathrm{b}}$ & $79.0^{\mathrm{b}}$ & 12.389 & Lin \\
Poultry by-product meal & $57.6^{\mathrm{b}}$ & $68.0^{\mathrm{b}}$ & $64.6^{\mathrm{b}}$ & $65.6^{\mathrm{c}}$ & $65.2^{\mathrm{c}}$ & 8.711 & $\mathrm{NS}$ \\
Poultry fat & $85.4^{\mathrm{a}}$ & $93.0^{\mathrm{a}}$ & $91.6^{\mathrm{a}}$ & $93.2^{\mathrm{a}}$ & $98.8^{\mathrm{a}}$ & 5.231 & Lin \\
\hline
\end{tabular}

Means followed by different letters in the column, differ by the Tukey Test, at $5 \%$ probability. ${ }^{1}$ CV: Coefficient of variation. NS: Non significative. Lin: linear effect by regression analysis. Source: Authors.

Among the three protein sources, MBM showed the lowest values of CAME $(\mathrm{P}<0.05)$ for all ages evaluated, which may be related to its processing and composition, since the contents of EE, GE and CP of MBM were lesser than TPR and PBM. In addition, MBM had the highest ash values (406.9 $\left.\mathrm{g} \mathrm{kg}^{-1}\right)$, compared to TPR $\left(253.7 \mathrm{~g} \mathrm{~kg}^{-1}\right)$ and PBM $\left(181.2 \mathrm{~g} \mathrm{~kg}^{-1}\right)$. In a study for prediction of metabolizable energy with PBM, Silva et al. (2010) highlighted that by-product meals with higher contents of mineral matter showed lower values of metabolizable energy, showing an antagonistic correlation, where higher contents of mineral matter, had lesser metabolizable energy values. The higher mineral contents with calcium and sodium ions, can also cause the saponification of fats present in animal flours, reducing their use by birds (Troni et al., 2016; Eyng et al., 2011).

Regarding the regression analysis (Table 5), there was a linear increase $(\mathrm{P}<0.05)$ for the CAME of TPR, PBM and PF with the birds age, however, there was no adjustment $(\mathrm{P}>0.05)$ in the regression for MBM. When corrected for nitrogen (CAMEn), there was a linear increase with birds age $(\mathrm{P}<0.05)$ only in TPR and PF while no effect $(\mathrm{P}>0.05)$ was found for PBM and MBM. Adeola et al. (2018) found quadratic effects in AME and AMEn in relation to the ages 0-7, 6-11, 10-16, and 15-21, wherein the day 0 to 7 energy values were lower than subsequent ages.

Table 5. Regression equations of the coefficient of apparent metabolizable energy (CAME) and CAME corrected for nitrogen balance (CAMEn) for animal by-products in function of birds age.

\begin{tabular}{lcccc}
\hline Item & \multicolumn{1}{c}{ CAME $^{1}$} & $\mathrm{R}^{2}$ & CAMEn & $\mathrm{R}^{2}$ \\
\hline Tilapia processing residue & $\mathrm{Y}=61.6292+0.514770 \mathrm{x}$ & 0.68 & $\mathrm{Y}=56.5490+0.477880 \mathrm{x}$ & 0.61 \\
Poultry by-product meal & $\mathrm{Y}=63.9095+0.181966 \mathrm{x}$ & 0.23 & - & - \\
Poultry fat & $\mathrm{Y}=82.6468+0.351434 \mathrm{x}$ & 0.76 & $\mathrm{Y}=85.8317+0.271770 \mathrm{x}$ & 0.64 \\
\hline
\end{tabular}

Source: Authors.

There was a linear increasing effect $(\mathrm{P}<0.05)$ for $\mathrm{CAME}$ and CAMEn with the advancing age of birds fed PF; this occurs due to increased ability of broiler chickens to use nutrients with age, since the most drastic changes occurs in the first 
weeks of life, being more pronounced with young birds fed sources rich in saturated fatty acids (Aardsma et al., 2017). Tancharoenrat et al. (2013) evaluated different fat sources including PF and found an improvement in AME with advancing birds age, the authors also highlighted the occurrence of lower AME values in birds from 0-7 d, which occurred in this study for CAMEn values.

\section{Conclusion}

Meat and bone meal energetic value was not influenced by age and showed the lesser energetic values. The CAME values of tilapia processing residue, poultry by-product meal and poultry fat increased with broiler chicken's age.

\section{References}

Aardsma, M. P., Mitchell, R. D. \& Parsons, C. M. (2017). Relative metabolizable energy values for fats and oils in young broilers and adult roosters. Poultry Science, 96(7), 2320-2329.

Adeola, O., Anwar, M. N., Abdollahi, M. R. \& Ravindran, V. (2018). Age-related energy values of meat and bone meal for broiler chickens. Poultry Science, $97,2516-2524$.

Amerah, A. M., Ravindran, V., Lentle, R. G. \& Thomas, D. G. (2007). Feed particle size: Implications on the digestion and performance of poultry. World Poultry Science Journal, 63, 439-445.

Amerah, A. M., Ravindran, V., Lentle, R. G. \& Thomas D. G. (2008). Influence of feed particle size on the performance, energy utilization, digestive tract development, and digesta parameters of broiler starters fed wheat- and corn-based diets. Poultry Science, 87, 2320 - 2328.

Anwar, M. N., Ravindran, V., Morel, P. C. H., Ravindran, G. \& Cowieson, A. J. (2016). Measurement of true ileal calcium digestibility in meat and bone meal for broiler chickens using the direct method. Poultry Science, 95, 70-76.

Caires, C. M., Fernandes, E. A., Fagundes, N. S., Carvalho, A. P., Maciel, M. P. \& Oliveira, B. R. (2010). The use of animal byproducts in broiler feeds. Use of animal co-products in broilers diets. Brazilian Journal of Poultry Science, 12(1), 41-46.

Cao, M. H. \& Adeola, O. (2016). Energy value of poultry byproduct meal and animal-vegetable oil blend for broiler chickens by the regression method. Poultry Science, 95, 268-275.

Cobb-Vantress. (2008). Manual de manejo de frangos de corte Cobb. Cobb-Vantress Brasil Ltda. https://wp.ufpel.edu.br/avicultura/files/2012/04/CobbManual-Frango-Corte-BR.pdf

Dalólio, F. S., Silva, D. L., Albino, L. F. T., Nunes, R. V., Ribeiro Júnior, V., Rostagno, H. S., Ferreira Junior, H. C. \& Pinheiro, S. R. F. (2019). Energy values and standardized ileal digestibility of amino acids in some feedstuffs for broilers. Semina: Ciências Agrárias, 40(6), 2651-2662.

Eyng, C., Nunes, C. G. V., Nunes, R. V., Rostagno, H. S., Albino, L. F. T., Vieites, F. M. \& Pozza, P. C. (2011). Composição química, valores energéticos e digestibilidade verdadeira dos aminoácidos de farinhas de carne e ossos e de peixe para aves. Revista Brasileira de Zootecnia, 40(3), 575-580.

Eyng, C., Nunes, R. V., Murakami, A. E., Pozza, P. C., Scherer, C., Silva, W. T. M. \& Bruno, L. D. G. (2013). Deposição de proteína e gordura nos cortes nobres de frangos alimentados com farinha de resíduos da indústria de filetagem de tilápia. Semina: Ciências Agrárias, 34(2), 875-882.

Hill, F. W. \& Anderson, D. L. (1958). Comparison of metabolizable energy and productive energy determinations with growing chicks. Journal of Nutrition, 64, 587-604.

Kato, R. K., Bertechini, A. G., Fassani, E. J., Brito, J. A. G. \& Castro, S. F. (2011). Metabolizable energy of corn hybrids for broiler chickens at different ages. Ciência e Agrotecnologia, 35(6), 1218-1226.

Mariano, F. C. M. Q., Lima, R. R., Rodrigues, P. B., Alvarenga, R. R. \& Nascimento, G. A. J. (2012). Prediction equations of energetic values of feedstuffs obtained using meta-analysis and principal components. Ciência Rural, 42, 1634-1640.

Matterson, L. D., Potter, L. M., Stutz, M. W. \& Singsen, E. P. (1965). The metabolizable energy of feed ingredients for chickens. Agricultural Experiment Station Research Report. 7, 11-14.

Rodrigues, P. B., Martinez, R. S. \& Freitas, R. T. F. (2005). Influência do tempo de coleta e metodologias sobre a digestibilidade e o valor energético de rações para aves. Revista Brasileira de Zootecnia, 34(3), 882-889.

Rodriguez-Sanchez, R., Tres, A., Sala, R., Guardiola, F. \& Barroeta, A. C. (2019). Evolution of lipid classes and fatty acid digestibility along the gastrointestinal tract of broiler chickens fed different fat sources at different ages. Poultry Science, 98,1341-1353.

Rostagno, H. S., Albino, L. F. T., Donzele J. L., Gomes, P. C., Oliveira, R. F., Lopes, D. C., Ferreira, A. S., Barreto, S. L. T. \& Euclides, R. F. (2011). Tabelas brasileiras para aves e suínos: composição de alimentos e exigências nutricionais (pp. 17-32). 3 ed. Viçosa, MG. 
Rostagno, H. S., Albino, L. F. T., Hannas, M.I., Donzele, J. L., Sakomura, N. K., Perazzo, F. G., Saraiva, A., Teixeira, M. L., Rodrigues, P. B., Oliveira, R. F., Barreto, S. L. T. \& Brito, C. L. (2017). Tabelas brasileiras para aves e suínos: composição de alimentos e exigências nutricionais. 4 ed. Viçosa: Universidade Federal de Viçosa.

Statistical Analysis System Institute (2011). SAS User's Guide: Statistics. Version 9.3 Edition. Cary, NC: SAS Inst. Inc.

Schneiders, J. L., Nunes, R. V., Schöne, R. A., Frank, R., Savoldi, T. L., Tsutsumi, C. Y., Scherer, C. \& Castilha, L. D. (2017). Energy coefficients of plant foods for broiler chickens at different ages. Semina: Ciências Agrárias, 38(4), 2119-2128.

Sibbald, I. R. \& Slinger, S. J. (1963). A biological assay for metabolizable energy in poultry feed ingredients together with findings which demonstrate some of the problems associated with evaluation of fats. Poultry Science, 42, 13-25.

Skřivan, M., Marounek, M., Englmaierová, M., Čermák, L., Vlčková, J., Vlčková, J. \& Skřivanová, E. (2018). Effect of dietary fat type on intestinal digestibility of fatty acids, fatty acid profiles of breast meat and abdominal fat, and mRNA expression of lipid-related genes in broiler chickens. Plos one, 13(4), e0196035.

Silva, E. P., Rabello, C. B., Albino, L. F. T., Ludke, J. V., Lima, M. B. \& Dutra Junior, W. M. (2010). Prediction of metabolizable energy values in poultry offal meal for broiler chickens. Revista Brasileira de Zootecnia, 39(10), 2237-2245.

Silva, E. P., Rabello, C. B., Lima, M. B., Arruda, E. M. F., Ludke, J. V. \& Ludke, M. C. M. M. (2012). Determination of the chemical composition, amino acid levels and energy values of different poultry offal meals for broilers. Brazilian Journal of Poultry Science, 14(2), 71-158.

Silva, E. P., Rabello, C. B., Lima, M. B., Ludke, J. V., Arruda, E. M. F. \& Albino, L. F. T. (2014). Poultry offal meal in broiler chicken feed. Scientia Agricola, 71(3), 188-194.

Silva, D. J., \& Queiroz, A. C. (2002). Análises de alimentos (métodos químicos e biológicos). (3a ed.) Editora UFV.

Soares Neto, J. R., Ribeiro, F. A. S., Gonçalves, A. A. \& Emerenciano, M. G. C. (2019). Tilapia processing waste silage (TPWS): An alternative ingredient for Litopenaeus vannamei (Boone, 1931) diets in biofloc and clear-water systems. Aquaculture and Fisheries, 4, $214-218$.

Tancharoenrat, P., Ravindran, V., Zaefarian, F. \& Ravindran G. (2013). Influence of age on the apparent metabolisable energy and total tract apparent fat digestibility of different fat sources for broiler chickens. Animal Feed Science and Technology, 186, 186-192.

Troni, A. R., Gomes, P. C., Mello, H. H. C., Albino, L. F. T. \& Rocha, T. C. (2016). Composição química e energética de alimentos para frangos de corte. Revista Ciência Agronômica, 47(4), 755-760.

Vieira, S. L., Kindlein, L., Stefanello, C., Simoes, C. T., Santiago, G. O. \& Machado, L. P. (2015). Energy utilization from various fat sources by broiler chickens at different ages. International Journal of Poultry Science, 14(5), 257-261.

Xu, Y., Stark, C. R., Ferket, P. R., Williams, C. M., Pacheco, W. J. \& Brake, J. (2015). Effect of dietary coarsely ground corn on broiler live performance, gastrointestinal tract development, apparent ileal digestibility of energy and nitrogen, and digesta particle size distribution and retention time. Poultry Science, $94,53-60$

Zanotto, D. L. \& Bellaver, C. (1996). Método de determinação da granulometria de ingredientes para uso de rações de suínos e aves. Comunicado técnico 215. EMBRAPA-CNPSA, Concórdia, SC. 